\title{
Development of a smart system for diagnosing the operating conditions of a
}

\section{helicopter prototype via vibrations analysis}

\author{
Desenvolvimento de um Sistema inteligente para diagnóstico da condição de operação de um \\ protótipo de helicóptero via análise de vibrações \\ Proyecto de un sistema inteligente para diagnosticar el estado operativo de un prototipo de
}

helicóptero mediante análisis de vibraciones

Received: 09/13/2021 | Reviewed: 09/19/2021 | Accept: 09/20/2021| Published: 09/22/2021

João Manoel de Oliveira Neto

ORCID: https://orcid.org/0000-0002-3199-172X

Federal University of Paraiba, Brazil

E-mail joao.oliveira@estudantes.ufpb.br

Andersson Guimarães Oliveira

ORCID: https://orcid.org/0000-0002-6472-7941

Federal University of Alagoas, Brazil

E-mail: andersson.oliveira@ceca.ufal.br

João Vitor Lira de Carvalho Firmino

ORCID: https://orcid.org/0000-0002-1537-1934 Federal University of Paraiba, Brazil

E-mail: vitor.carvalho.lira@hotmail.com

Marcelo Cavalcanti Rodrigues

ORCID: https://orcid.org/0000-0002-3663-5097

Federal University of Paraiba, Brazil

E-mail: marcelo.labii@gmail.com

Antônio Almeida Silva

ORCID: https://orcid.org/0000-0002-7130-8542

Federal University of Campina Grande, Brazil

E-mail: antonio.almeida@ufcg.edu.br

Laura Hecker de Carvalho

ORCID https://orcid.org/0000-0003-3118-0123

Federal University of Campina Grande, Brazil

E-mail: heckerdecarvalho@yahoo.com.br

\begin{abstract}
In the forward flight, wind loads affect the helicopters and cause vibration. This paper analyzes the behavior of a helicopter prototype composed by two blades when subjected to a front wind load, similar to the forwarding flight condition. An Artificial Neural Network (ANN) processes the experimental data in order to identify the pattern of its dynamic behavior. The tests led to Vibration analysis for different wind speeds. Also, the data indicates that vibration amplitude increases when the blades are subjected to the fundamental frequency and its first harmonic on tests conducted without rotor plane tilt (hover flight). On the other hand, the second test performs a 5-degree tilt on the rotor disc. In this test, the vibration amplitude decreased in the fundamental frequency, and the amplitude related to the first harmonic increased. The ANN achieved 100\% efficiency in recognizing the flight conditions of the prototype. Keywords: Vibration analysis; Helicopter; Artificial neural network; Forward flight.
\end{abstract}

\section{Resumo}

No voo para a frente, as cargas do vento afetam os helicópteros e causam vibração. Este artigo analisa o comportamento de um protótipo de helicóptero composto por duas pás quando submetido a uma carga de vento frontal, semelhante à condição de voo de avanço. Uma Rede Neural Artificial (RNA) processa os dados experimentais para identificar o padrão de seu comportamento dinâmico. Os testes levaram à análise de vibração para diferentes velocidades do vento. Além disso, os dados indicam que a amplitude de vibração aumenta quando as pás são submetidas à excitação na frequência fundamental e seu primeiro harmônico em testes realizados sem inclinação do plano do rotor (voo pairado). Por outro lado, o segundo teste submete o protótipo a uma inclinação de 5 graus no disco do rotor. Neste teste, a amplitude de vibração diminuiu na frequência fundamental, e a amplitude relacionada ao primeiro harmônico aumentou. A RNA alcançou $100 \%$ de eficiência no reconhecimento das condições de voo do protótipo.

Palavras-chave: Análise de vibrações; Helicóptero, Rede neutral artificial; Voo a frente. 


\section{Resumen}

En el vuelo hacia adelante, las cargas del viento afectan los helicópteros y provocan vibración. Este artículo analiza el comportamiento de un prototipo de helicóptero compuesto por dos palas cuando se somete a una carga de viento en contra, similar a la condición de vuelo de avanzo. Una Red Neuronal Artificial (RNA) procesa los datos experimentales para identificar el patrón de su comportamiento dinámico. Las pruebas condujeron al análisis de vibración para diferentes velocidades del viento. Además, los datos indican que la amplitud de vibración aumenta cuando las palas se someten a la excitación en la frecuencia fundamental y su primer armónico en pruebas realizadas sin inclinación del plano del rotor (vuelo estacionario). Por otro lado, la segunda prueba somete al prototipo a una inclinación de 5 grados sobre el disco del rotor. En esta prueba, la amplitud de vibración disminuyó en la frecuencia fundamental, y la amplitud relacionada con el primer armónico aumentó. La RNA alcanzó 100\% de eficiencia en el reconocimiento de las condiciones de vuelo del prototipo.

Palabras clave: Análisis de vibraciones; Helicóptero, Red artificial neutral; Vuelo por delante.

\section{Introduction}

Helicopters are widely used for several applications for civil and military purposes. Technological advances optimize helicopters parts to improve their ability to sustain hovered flights, according to FAA (2012).

In a helicopter, the lifting stems from the blades' movement in the rotor. A downward movement pushes the air when the blades spin. As the air pressure changes, the helicopter lifts as a reaction to the thrust.

Since helicopters have blades that revolve around a fixed point, it is possible to handle some aspects of the helicopter's dynamics as performed in ordinary rotating machinery (Johnson, 1994; Vance et al., 2010).

According to bramwell et al.(2001), the predominant vibration source is caused by interaction between the blades and the air around them. From this perspective, vibration energy goes through blades and the main shaft, reaching the fuselage and the crew. Therefore, international standards have established the vibration limits which crew tolerates and according to the machine's structural integrity (RTCA DO-160C, 2014).

Helicopter vibration increases maintenance costs and affects flying safety. Therefore, the European Union Aviation Safety Agency, EASA,(2020), in its annual safety review, considers system failures, technical failures, and aircraft maintenance represent a relevant risk.

Similarly, the Center of Investigation and Prevention for Aeronautical Accidents CENIPA (2017), in Brazil, statistically reports that system failures, system malfunction, or lost control in flight represent $33 \%$ of accident causes. Thus, vibration is a possible cause or condition that anticipates or increases failure probabilities. Hence, vibrations measurements may improve maintenance routines.

Vibration health monitoring (VHM) is a combination of techniques to monitor the condition of a critical rotor and its components to improve fault detection. The European Aviation Safety Agency EASA (2021) recognizes the importance of vibration analysis for machine health, which motivates the use of VHM to improve traditional inspection techniques.

Reliable predictive techniques provide a better understanding of the machine's dynamic response and may identify any malfunction. In this context, regulatory agencies approve these techniques desired by manufacturers and customers around the world.

The identification of undesirable vibrations by artificial intelligence techniques such as Artificial Neural Networks (ANN) is an efficient tool for malfunction pattern recognition of machine vibration signals. Rotating machinery uses several ANN techniques to identify failure patterns. From this perspective, vibration analysis is one of them and it is used for failure identification in different gear models, according to Waqar and Demetgul (2016), Sanz et al. (2012) and (Saravanan \& Ramachandran (2010). Moreover, vibration analysis by sound waves was used to identify induced failures in bearings, according to Sadegh et al. (2016), in electrical induced three-phase motor, as mentioned by Glowacz (2018), in helical gears according to Glowacz et al. (2018), and internal combustion engine, as the work performed by Wu and Chan (2009). When it 
comes to a helicopter operation analysis, an ANN was successfully developed by Dong (2018) to identify flight parameters for the detection and characterization of aircraft icing.

This paper proposes the use of a smart system based on a multilayer perceptron ANN, with a backpropagation algorithm, to identify different flight situations (hover and forward flight) by using vibration signals of a helicopter rotor prototype. In both conditions, the prototype was subjected to three wind load conditions. For data acquisition, vibration signals were collected on the time domain and converted to the frequency domain via FFT. Then, it was extracted the main features from the acquired signal and created a database that enabled the ANN to distinguish between eight different operation categories. For each operation condition, we collected 20 signals, totaling 160 input signals for the ANN.

\section{Methodology}

The methodological approach consists in use a prototype to study the outputs (dynamic response of the system) according to the inputs (external parameters changing) performing measurements in the output signals. The experiments were conducted on a helicopter prototype, as shown in Figure 1. Thus this research can be classified as an experimental and quantitative research (Pereira et al., 2018). Yet, before the experimental procedure, the prototype was tested in order to ensure the properly working, vibrating signal measurements and sensors testing as an exploratory experimentation (Doebelim, 1995). Thus, an ideal reference working condition was stablished so, that the signals from this condition was assumed as a reference.

Considering the comparative analysis method, both the prototype in reference condition and the prototype in different slopes use the same test machine. This model has a main shaft, engine, and gearbox, taken from a hobby model. The prototype also has two blades and a DC motor attached to the gearbox. The main shaft frequency is adjusted by electrical current shifting in the DC motor connected to the power supply.

Figure 1 - Helicopter Prototype. a) general view b) upper view.

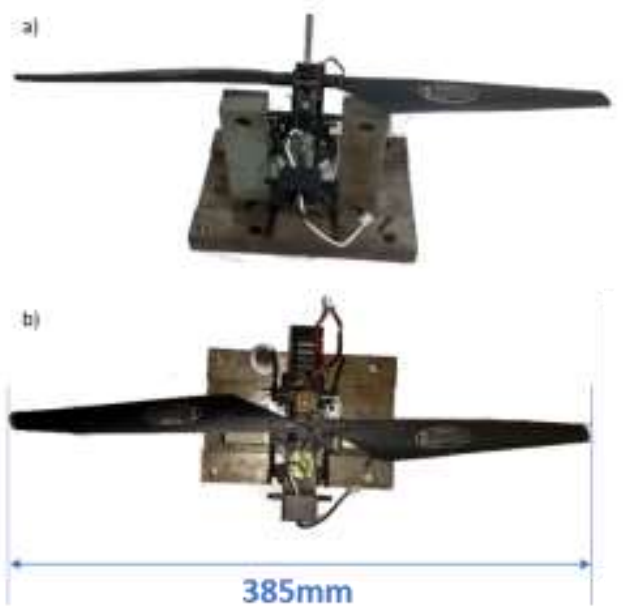

Source: Authors.

For the test performances, the prototype was assembled on an inertial table. A blower generates frontal and constant airflow to simulate forward wind during normal flying. The prototype shows a simple blade mechanism without a swashplate. Thus, the pitch angle is constant in all experiments. Tilt angle shifting is performed by the tilt in the prototype chassis plane.

The experiment performed three airflow velocities: low $(2 \mathrm{~m} / \mathrm{s})$, medium $(5 \mathrm{~m} / \mathrm{s})$, and high $(10 \mathrm{~m} / \mathrm{s})$. Airspeed represents the forwarding flight. Regarding the acquisition stage, a Signal Analyzer (Agilent 35670A) and a PCB (35ZB10) 
accelerometer collect the vibration signals. Also, the anemometer AMI 300 measures the airspeed, and a tachometer estimates the rotor rotating speed. Figure 2 shows the instrumental equipment used in this research.

The accelerometer was placed on the rotor shaft through silicone rubber, and the vibration signal in the horizontal direction was analyzed using Matlab. Furthermore, the signal was collected from 0 to $200 \mathrm{~Hz}$ with a resolution of 800 lines.

When the rotor is parallel to the ground (no tilt angle), the operation condition may be no wind load (A1) and three different airspeeds $(\mathrm{B} 1=2 \mathrm{~m} / \mathrm{s}, \mathrm{C} 1=5 \mathrm{~m} / \mathrm{s}, \mathrm{D} 1=10 \mathrm{~m} / \mathrm{s})$.

Figure 2 - Experimental setup.

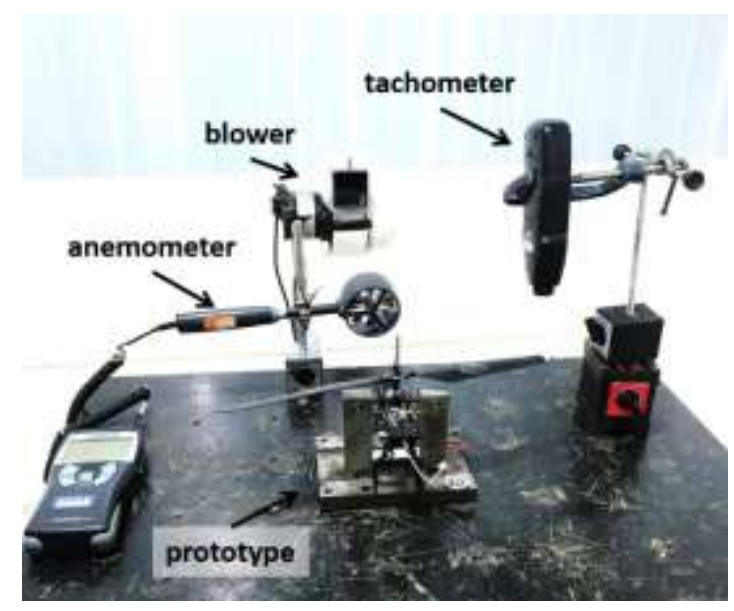

Source: Authors.

For the second flight condition, shown in Figure 3, the rotor works with a $5^{\circ}$ tilt angle, and it is subjected to the following operating conditions: no wind load (A2) and wind load caused by different airspeeds $(\mathrm{B} 2=2 \mathrm{~m} / \mathrm{s}, \mathrm{C} 2=5 \mathrm{~m} / \mathrm{s}$, and $\mathrm{D} 2=10 \mathrm{~m} / \mathrm{s})$.

Figure 3 - Instrumentation.

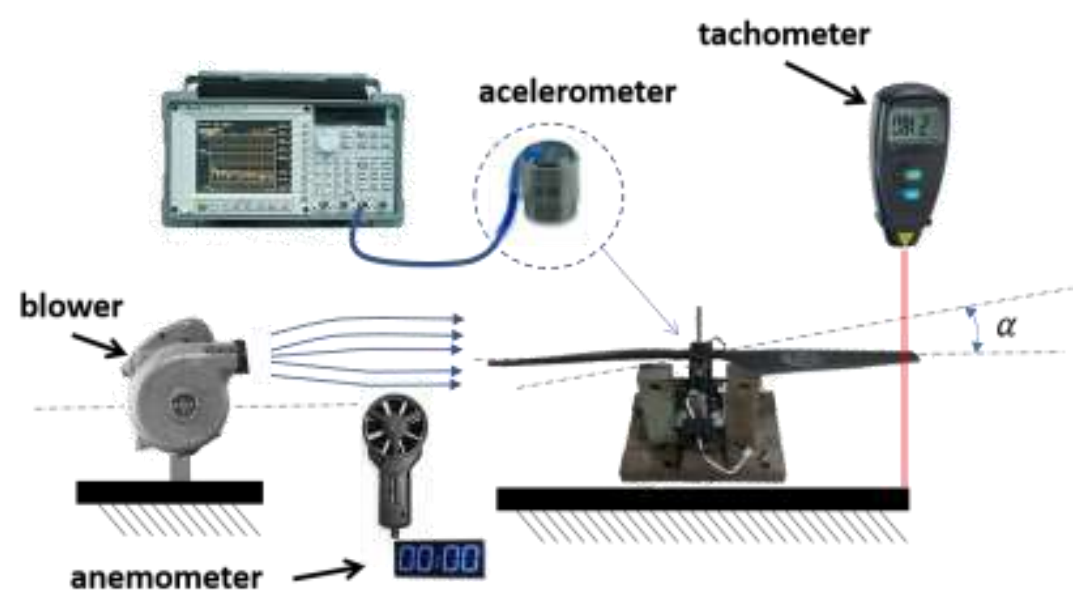

Source: Authors. 
After vibration data acquisition, the machine rotation speed was determined via FFT. The rotation frequency was found by comparing the frequency spectrum with the rotation velocity measured by the tachometer and considering that this frequency is twice that of the main shaft angular rotation because of the two-bladed prototype.

By analyzing the vibration signal, it was possible to detect the peaks associated with the rotation frequency and their harmonics by feature extraction and selection techniques. Then, we used these features to feed the MLP. Also, the signal energy was used as extra input for the MLP.

Regarding the frequency spectrum, operating parameters of the machine were selected for each specified condition in the vibration signals to enhance the ANN. These parameters are the features extracted from the signal, which corresponds to a pattern for each operating condition.

Thus, the features extracted from the vibration signal were about the locations of the peaks referring to the fundamental frequency and the second harmonic (passage frequency of the blades). Considering that the main changes in the signals occurred in these peaks and, therefore, in the energy, the increase of the rotation speed generates more energy and higher peaks in the vibration signals, as shown in Figures 18 and 19.

The operating conditions identified by the MLP are categorized into two groups: operation without tilt (hovering flight) and operation with tilt (forward flight).

For hovering flight, the prototype is subjected to the following load models:

- flight without frontal wind (A1)

- flight with frontal wind $-2 \mathrm{~m} / \mathrm{s}$ (B1)

- flight with frontal wind $-5 \mathrm{~m} / \mathrm{s}(\mathrm{C} 1)$

- flight with frontal - 10m/s (D1)

For forward flight, the prototype is subjected to the following load models:

- flight without frontal wind (A2)

- flight with frontal wind $-2 \mathrm{~m} / \mathrm{s}$ (B2)

- flight with frontal wind $-5 \mathrm{~m} / \mathrm{s}(\mathrm{C} 2)$

- flight with frontal - 10m/s (D2)

For each operating condition, the frequency, the five prominent amplitudes, and the energy were selected and used as input for the ANN. On the other hand, the ANN output is determined by the classes to be recognized. Since the network developed in this research has eight different classes to identify, there are also eight possible responses for the ANN.

Although there are only two peaks of greater interest in the signal (fundamental frequency and frequency of passage of the blades), the use of five peaks was adopted to reduce the network confusion in its training stage.

Figure 4 shows the frequency spectrum of the prototype in operation, where the location of the five peaks of interest is exposed. Additionally, these peaks are located between 0 and $50 \mathrm{~Hz}$ because the fundamental frequency (first peak located in Figure 4 and the blades' frequency (second peak Figure 4 located in) are within this range. 
Figure 4 - Location of the five points extracted as characteristics of the signal for ANN construction.

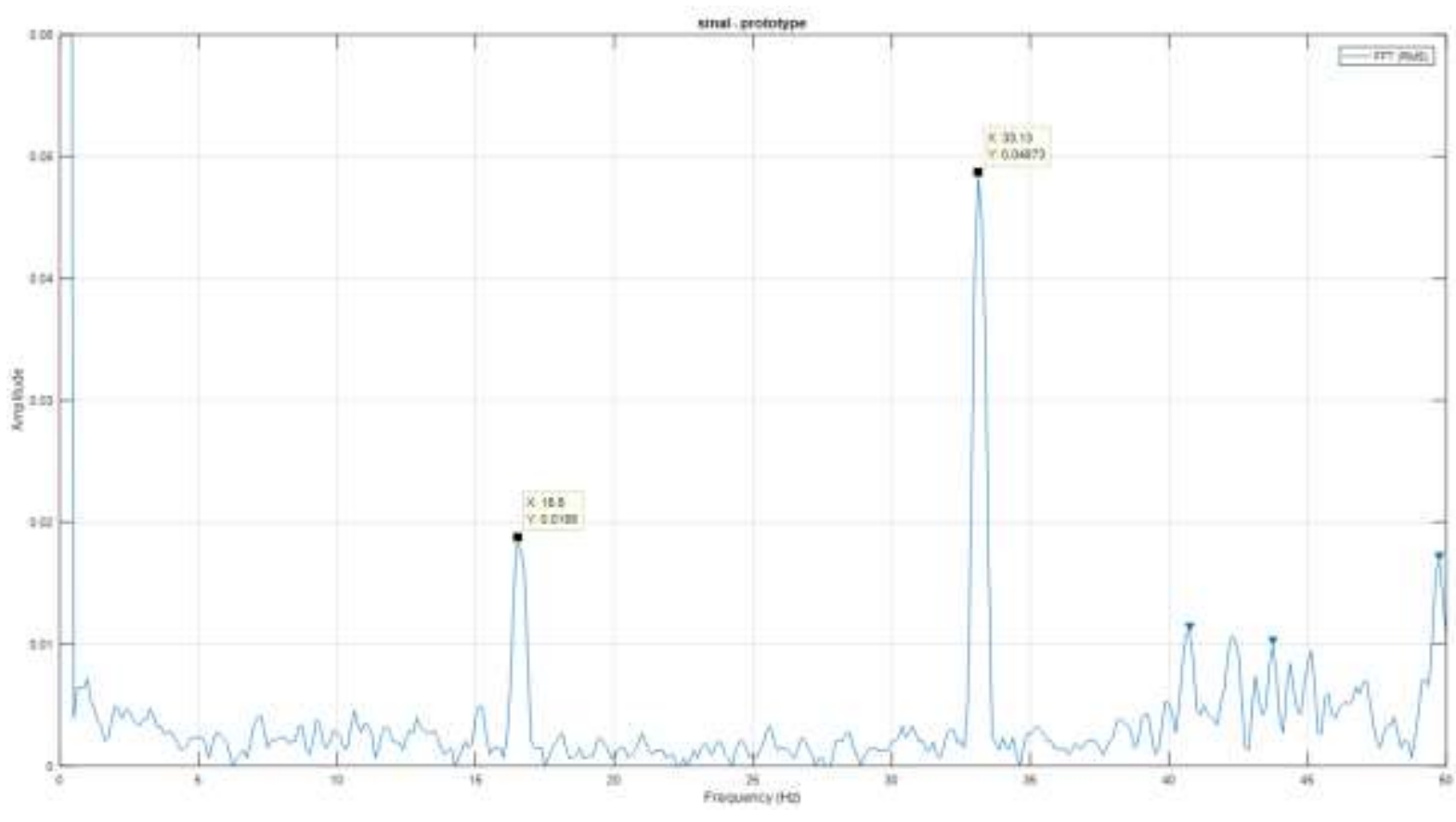

Source: Authors.

The data acquisition stage provided 20 signals for each configuration. By using the acquired signals, $70 \%$ of the vibration data were used for training, $15 \%$ for tests, and $15 \%$ for validation. The MLP developed reached the ideal values by varying the number of neurons in the hidden layer and the learning rate. The activation function adopted by the MLP was the tangent sigmoid in the hidden layer and the log-sigmoid in the output layer, as shown in Figure 5.

Figure 5 - MLP representation.

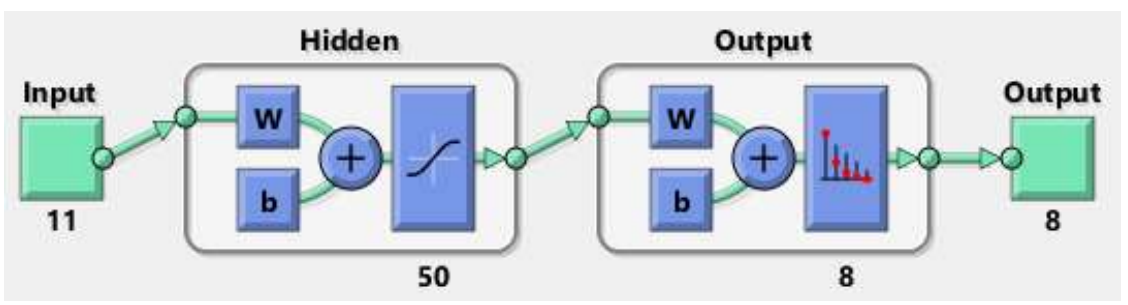

Source: Authors.

\section{Theoretical background}

\subsection{Helicopter rotor dynamics}

For the dynamic analysis, it is crucial to notice the wide variety of helicopter rotor arrangements. In this context, Figure 6 shows three of the main rotor configurations.

Due to the counter-torque generation, the axial and tandem rotors (Figure $6 \mathrm{~b}$ and Figure 6c) dismiss the tail rotor. Otherwise, most traditional helicopters adopt a single main rotor with a vertical shaft and a tail rotor (Figure 6a).

In general, helicopters may turn in all directions, and they are capable of performing three basic movements: hover, forward, and reverse flights. 
The hover flight has the rotor plane parallel to the ground. On the other hand, the forward and reverse flights have the tip path plane tilted toward the ground. Other maneuvers stem from a combination of these traditional movements.

Figure 6 - Rotor Types: a) Tail rotor b) coaxial c) tandem.

a)

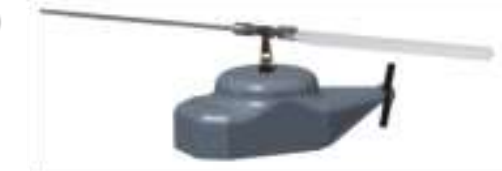

b)

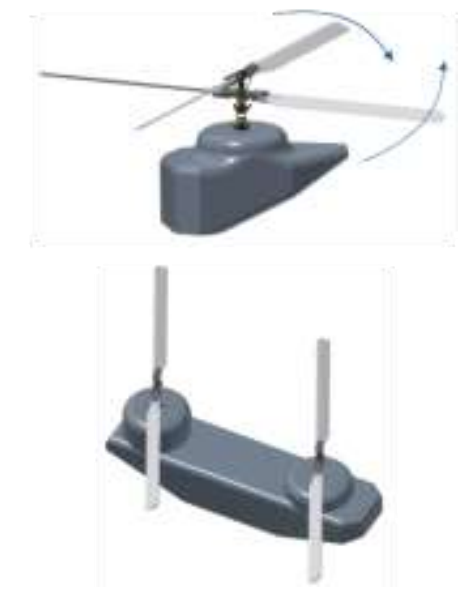

Source: Authors.

In order to change flight direction, it is necessary to shift the rotor plane by acting on a mechanism that enables to change blades' attack angle simultaneously or individually, as shown in Figure 7.

Figure 7 - Blades' mechanism.

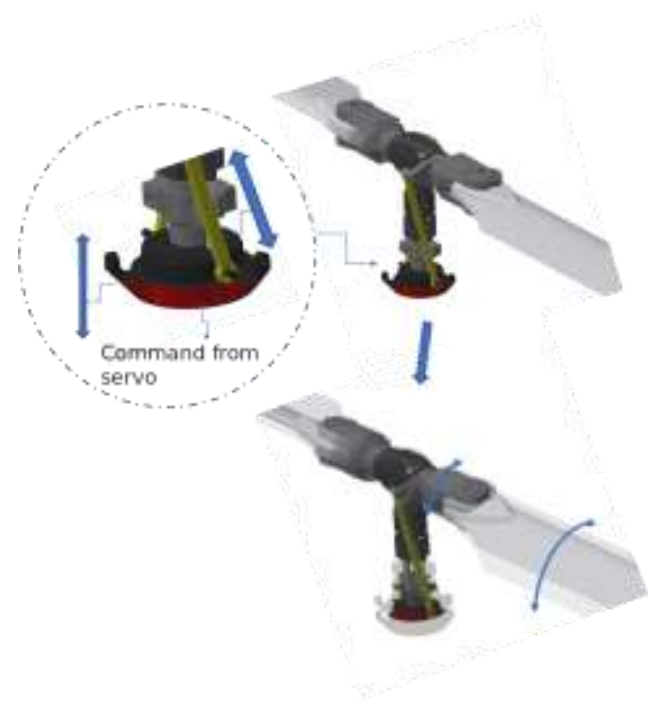

Source: Authors.

The blades' attack angle directly affects impulse changes. In this regard, the pilot uses subsystem servo-commands to transmit the movement on the blade angle. On a typical operation, the attack angle may shift in all blades simultaneously (collective command) or individually (cyclic command) to run the desired maneuver. 
The dynamic analysis assumes the rotor as a circular enclosed area, with infinite blades; therefore, its geometry is similar to a disk. In other words, to perform dynamic analysis, the rotor area may be represented as a continuous disc that rotates around the shaft. The volume control modeling on the rotor is shown in Figure 8.

Figure 8 - Rotor profile - volume control.

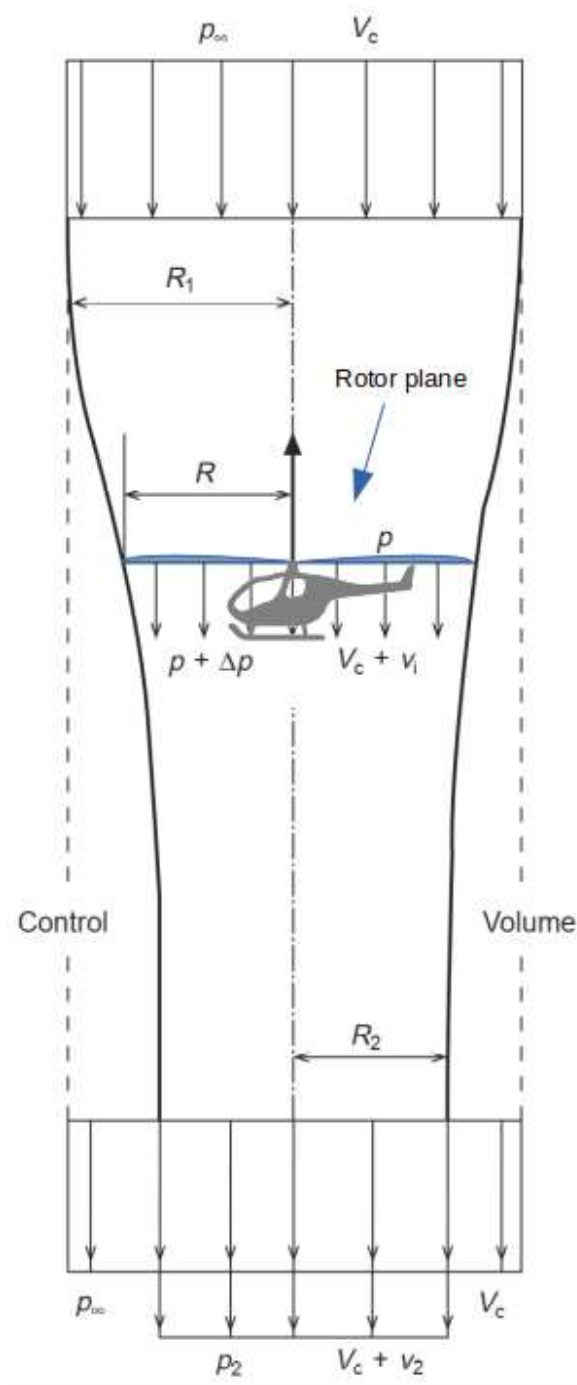

Source: Adapted from Bramwell et al. (2001).

In Figure $8, R_{l}$ is the region next to the rotor, where its influence is intense. Also, $R$ is the actual rotor radius, $V c$ is the relative airspeed, and $P_{\infty}$ is the atmospheric pressure.

Immediately after the airflow goes through the rotor, the airspeed is given by $V c+V i$, where $V i$ refers to the induced speed by the blades. Eq. 1 express the induced speed, and $T$ is the thrust load generated by the rotor, and A corresponds to the circular rotor area, according to bramwell et al. (2001).

$$
V_{i}=\sqrt{\frac{T}{2 \rho A}}
$$


The most critical flight condition takes place during tilt-rotor maneuvers. During the forward flight, on steady-state, periodic forces originated on the blades are transmitted to the fuselage, which generates vibration. In this flight condition, the air mass hits the rotor blades with velocity $\mathrm{V}$, the same as the rotor's upstream speed. This airflow deviates downward, a phenomenon known as downwash, which induces normal force components, as shown in Figure 9.

Figure 9 - Forward flight velocity components.

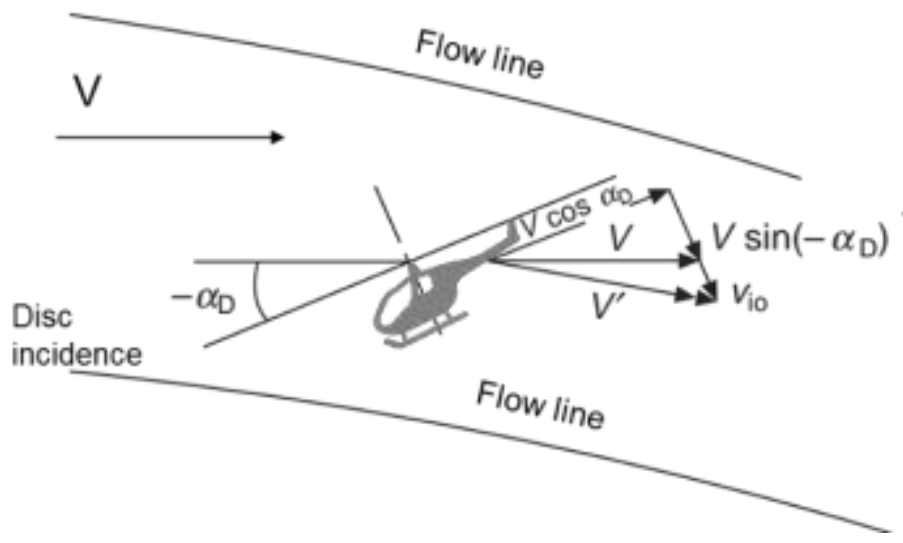

Source: Adapted from Bramwell et al. (2001).

Thus, on the forward flight, the induced velocity is represented by Eq. 2, considering that $V^{\prime}$ is tangent to the flow lines.

$$
V_{i}=\frac{T}{2 \rho A V^{\prime}}
$$

Therefore, two main flight conditions generate different dynamic behaviors: hover and tilt flight. In the hovering flight, the aircraft moves only in the vertical direction. Hence, there is uniform airflow through the rotor, besides the uniform load on the rotor disc area. In the forward flight, the tilt rotors generate two velocity components: $\mathrm{V}$ (horizontal direction) and V' (tangent to flow lines).

According to Zagaglia et al. (2018) and De Gregorio (2012), the following parameters corresponds to causes of vibrations in helicopters: airflow impact on the rotor blades, oscillatory loads on blades, aerodynamics between downwash air and fuselage, and other vibration causes.

\subsection{Helicopter Vibration analysis}

According to (Damy, 2006) and Ford (1999), the blades' aerodynamic (forces and moments) and inertial forces act directly on the rotor head, adding and subtracting its effects since the helicopter's principal vibration source is the main rotor.

The helicopter's vibration spectrum is composed of several components, such as multiples of the blades' passage frequency and rotor frequency $\Omega$, among other vibration sources.

In hovering flights, the load is equally distributed on the aircraft's blades. Consequently, low vibration levels and homogeneous load distribution are observed. On the other hand, each maneuver that changes the machine's dynamic 
equilibrium causes different load distribution and induces alternate loads in a condition known as lift dissymmetry, according to Johnson (1994) and represented in Figure 10.

Figure 10 - Dynamic load rotor distribution during forward flight.

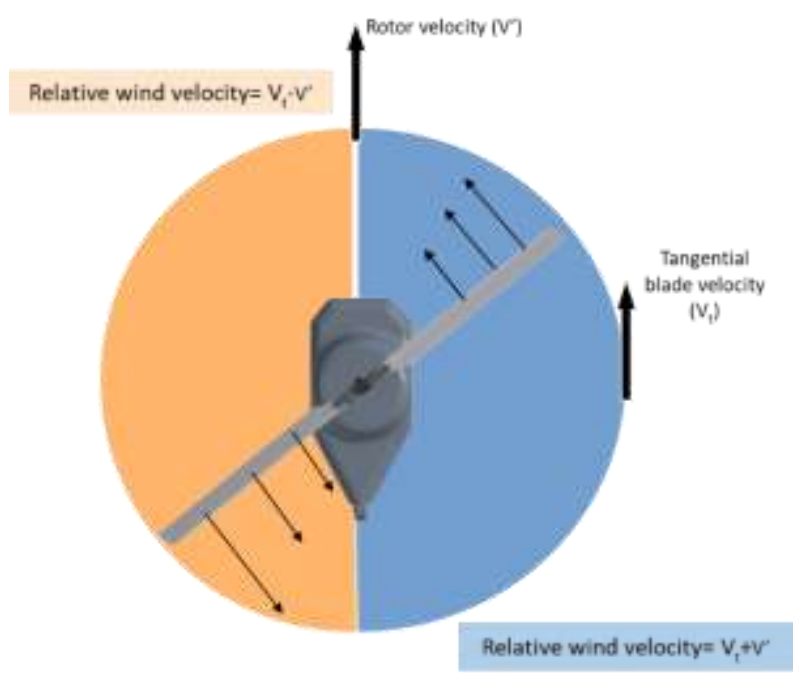

Source: Adapted from FAA (2012a).

Also, the load distribution in the forward blade is different from the one in the retreating one since there are differences between relative wind on each blade. Thus, resultant forces are non-uniform in forwarding flight or during a lateral gust on the aircraft.

\subsection{Vibration Measurement in helicopters}

In 2006, Damy (2006) analyzes the vibration signals on the Esquilo AS-355 F2 helicopter. In this work, he applied a portable signal analyzer and accelerometers on the rotor shaft and on the pilot cockpit. The aircraft and instrumentation details are presented in Figure 11.

Figure 11 - Instrumentation on the Esquilo AS355 F2 Helicopter. a) accelerometer on the pilot cockpit b) accelerometer on the rotor shaft structure c) Esquilo Helicopter.

a)

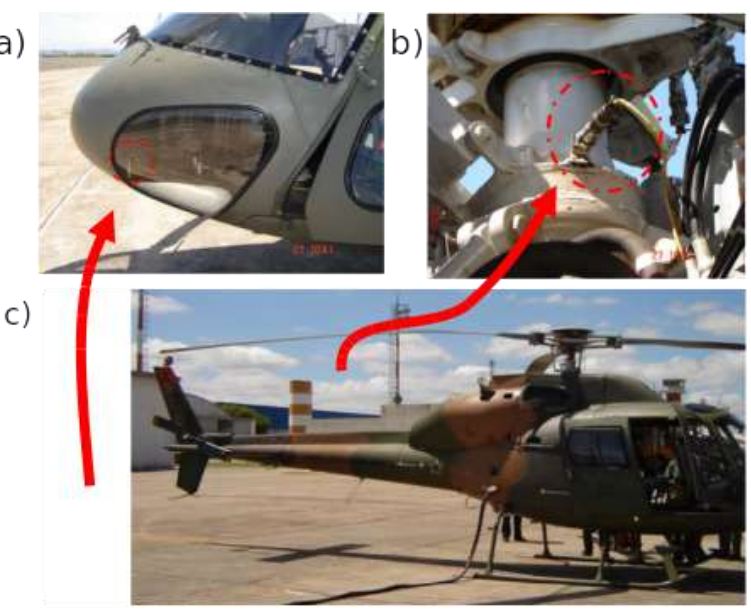

Source: Adapted from Damy (2006). 
The results obtained are shown in Figure 12.

Figure 12 - Amplitude vibration response in the Esquilo Helicopter Model.

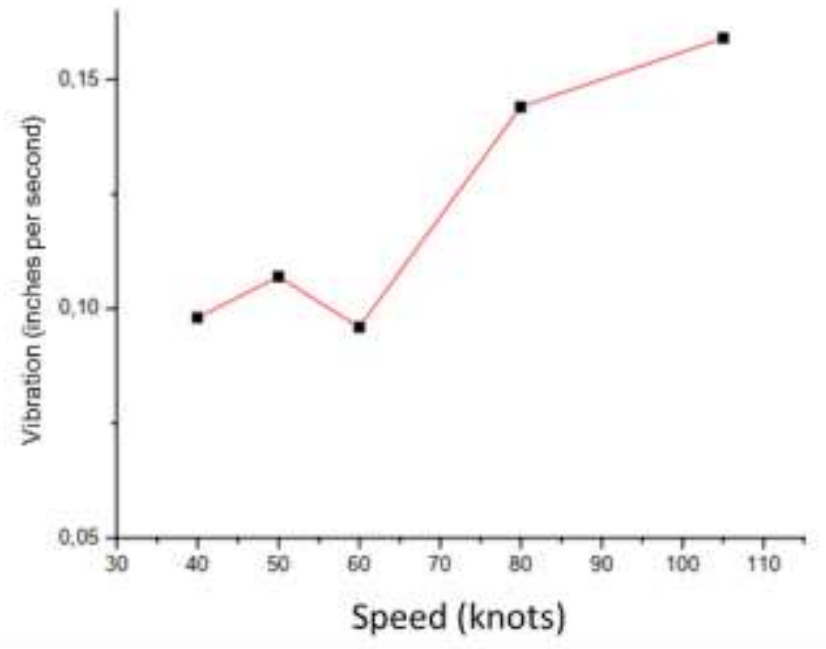

Source: Adapted from Damy (2006).

Figure 12shows that the vibration amplitude increases with increasing rotating speed. Therefore, vibration amplitude limits the helicopters' speed.

In an experiment with the Gazelle AS-342 helicopter, Stupar et al. (2012) uses accelerometers to measure the vibration amplitudes in two flight profiles: hover flight (aircraft remains horizontally 10 meters above the ground) and forward flight (aircraft moving forward at full speed). In this arrangement, the accelerometers were fixed in the pilot seat region, labeled $\mathrm{Ch} 1, \mathrm{Ch} 2$, and $\mathrm{Ch} 3$ distributed according to Table 1.

Table 1 - Vibration sensor positioning for vibration measurements.

\begin{tabular}{ccc} 
Channel & Direction & Location \\
\hline Ch1 & Longitudinal & Run access to pilot seat \\
\hline Ch2 & Vertical & Floor, in front of the pilot seat \\
\hline Ch3 & Vertical & Floor, in front of the pilot seat. Below the seat \\
& \multicolumn{2}{c}{ Fonte: Stupar et al. (2012). }
\end{tabular}

Figure 13 shows the experimental results. In this circumstance, the fundamental harmonic is $19,35 \mathrm{~Hz}$. The results detected a vibration increase in the harmonic multiples. 
Figure 13 - Flying profiles from the Gazelle helicopter experiment.
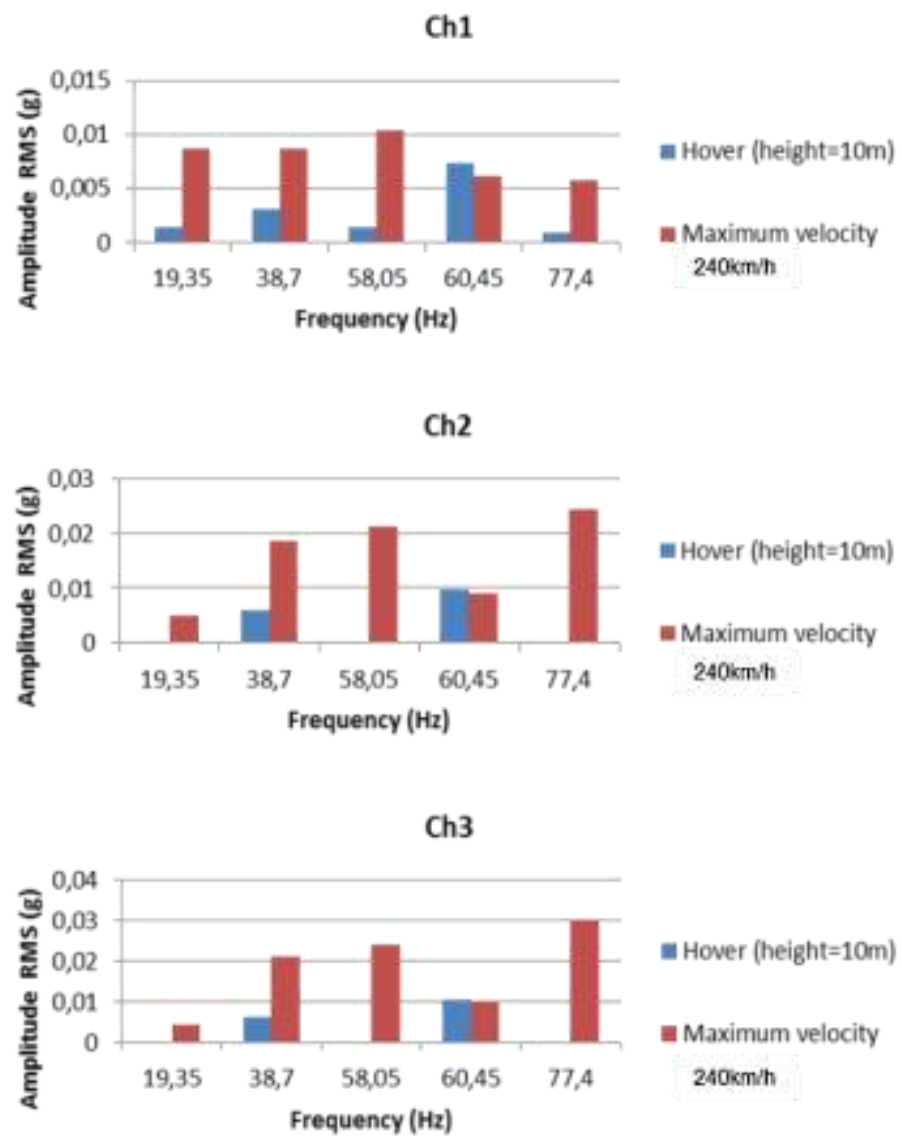

Source: Adapted from Stupar et al. (2012).

Both results, expressed in Figure 12 and Figure 13, indicate that vibration increases with speed, which demonstrates the difficulty of designing a structure to avoid excessive vibration when the helicopter is subjected to real operating conditions.

These experiments were performed with real aircrafts. However, in situations where it is not possible to use helicopters due to machine unavailability or technological limitations, it's necessary to use computational simulation or prototypes at scale. This strategy is adopted in the experimental research conducted by Straub et al. (2018), which uses a smallscale prototype installed in a wind tunnel with instrumentation to measure vibration and acoustic emission, as shown in Figure 14. 
Figure 14 - Vibration and acoustic instrumentation of a scaled prototype.

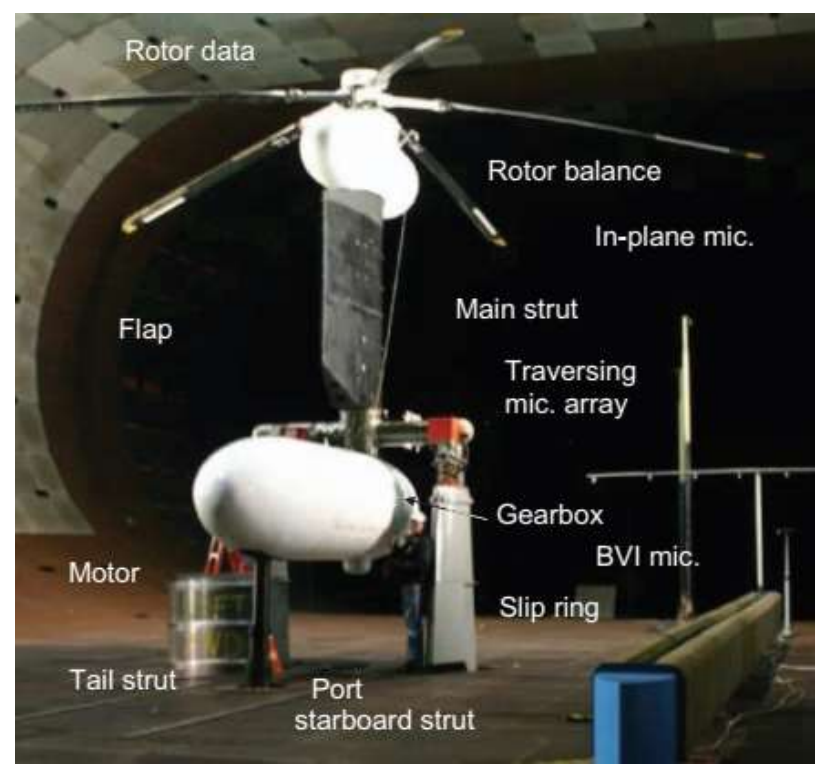

Source: Straub et al. (2018).

According to the researchers conducted by Straub et al. (2018) and Nguyen et al.(2018), it is possible to use smallscale prototypes or small aircraft to simulate real operating conditions and behavior. The experimental setup used by Nguyen et al.(2018) is presented in Figure 15.

Figure 15 - Quadcopter's dynamic measurements.
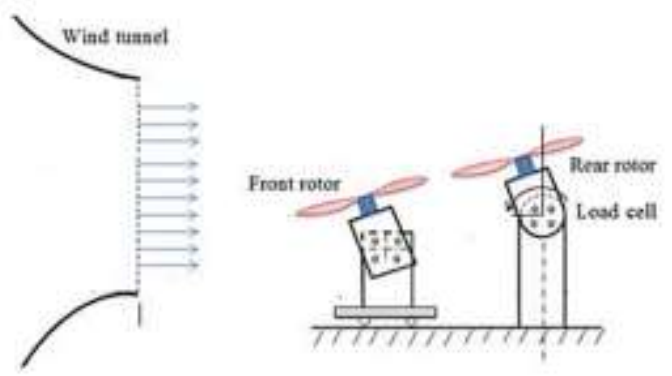

Source: Nguyen et al.(2018).

In both experiments, when it was not possible to measure vibration in a real aircraft, it was possible to reproduce forward flight conditions by applying frontal wind load on the rotor in order to simulate a real dynamic load.

\subsection{Signal processing technique}

The frequency spectrum evaluation is one of the most traditional techniques applied to vibration analysis. The sampled time-domain signals are represented by a sum of sinusoids with different phases and amplitudes. According to (Cavicchi, 1999), the fast Fourier transform (FFT) is a mathematical tool used to change the signal perspective from timedomain to frequency-domain.

The FFT is based on the Fourier series, represented by equations (3) to (5), where $a_{k}$ and $b_{k}$ are coefficients of the Fourier series. 
$f(t)=\frac{a_{0}}{2}+\sum_{k=1}^{\infty}\left(a_{k} \cos (2 \pi k t)+b_{k} \sin (2 \pi k t)\right.$

$a_{k}=\int_{0}^{2 \pi} f(t) \cos (2 \pi k t) d t$

$b_{k}=\int_{0}^{2 \pi} f(t) \sin (2 \pi k t) d t$
4)

The transformation of a time-domain signal into a frequency-domain signal is performed by equation (6). In this equation, $f(t)$ is the time-domain signal, $i$ is the imaginary number, and $\omega$ is the angular velocity, and $e^{i \theta}=\cos (\theta)+\sin (\theta)$.

$$
f(\omega)=\int_{-\infty}^{\infty} f(t) e^{-i \omega t} d t
$$

\subsection{Artificial Neural Network}

Waqar and Demetgul (2016) define an Artificial Neural Network (ANN) as a computational model based on the structure of a neural biologic system, which provides outputs according to the inputs received. The ANN is optimized by learning parameters. The pattern identification task presents significant results when adopted to diagnose failures in rotating machinery.

Generally, the ANNs for pattern recognition use backpropagation algorithms during learning. One of the most traditional artificial neural networks used for pattern recognition is the multilayer perceptron (MLP), which is characterized by at least one hidden layer placed between the input layer and the output layer, according to Silva et al. (2010).

According to Saravanan and Ramachandran (2010), the backpropagation algorithm is a supervised learning process characterized by the previous knowledge of the output response in the training stage Figure 16 presents a MLP, where W represents the synaptic weights applied between the layers, and the $\mathrm{x}$ corresponds to the input signal. 
Figure 16 - MLP representation.

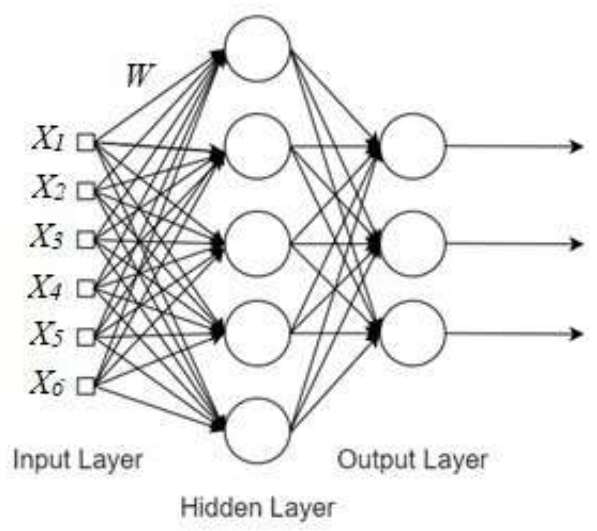

Source: Authors.

In this paper, the MLP developed has the following architecture: eleven neurons in the input layer, twenty neurons in a single hidden layer, and eight output neurons, which corresponds to the working conditions to be classified. A total of 160 vibration signatures of the rotating system were collected, 20 signatures for each operating condition. Therefore, we analyzed eight different classes established for the experiments. Then, for the MLP development, it was applied $70 \%$ of the acquired signals for training, $15 \%$ for validation, and $15 \%$ for tests.

\subsection{Feature Extraction and Selection}

In vibration analysis, it is possible to extract some of the machine's operation features from an acquired signal. In general, the correlation between vibration amplitudes and their associated frequencies in rotating machinery represents the most relevant signal characteristics.

Using the extracted features from the frequency spectrum directly on an MLP is computationally inefficient because of the large amount of data required. Therefore, it is necessary to select the main signal characteristics to improve MLP performance.

In this analysis, we extracted the fundamental frequency and its harmonics to use as ANN inputs. Also, for each frequency selected, we picked the associated amplitude. The signal energy was another feature extracted to feed the MLP Figure 17 shows the entire classification process for the helicopter prototype operating conditions. 
Figure 17 - Operation Condition Identification Process.

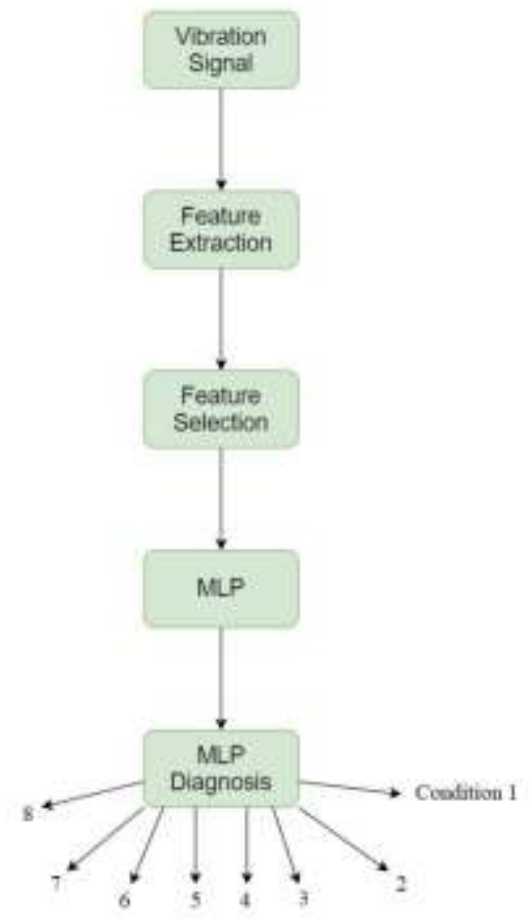

Source: Authors.

\section{Results}

For the frequency response, Figures 18 and 19 show the spectral signature of the prototype working in different conditions

Figure 18 shows the prototype simulating hovering flight, i.e., there is no rotor inclination. Conditions A1 and B1 have the fundamental frequency amplitude decreased. On the other hand, conditions C1 and D1 represent the prototype under different loads. In this situation, the model has the fundamental frequency amplitude increased because of the unbalanced loads on the structure. This result confirms the literature about operating conditions with unbalanced loads.

Additionally, Figure 19 shows that, for frequencies above $40 \mathrm{~Hz}$, further analysis was not necessary, considering that the fundamental frequency and the passage frequency of the blades are sufficient to understand the dynamic behavior of the prototype under different pre-established operating conditions. Furthermore, similar harmonics distribution is observed in Ceruti et al. (2011), where the authors describes the contribution of the gearbox and other mechanisms to the spectral response of the aircraft. 
Figure 18 - FFT - Operating condition with no inclination.

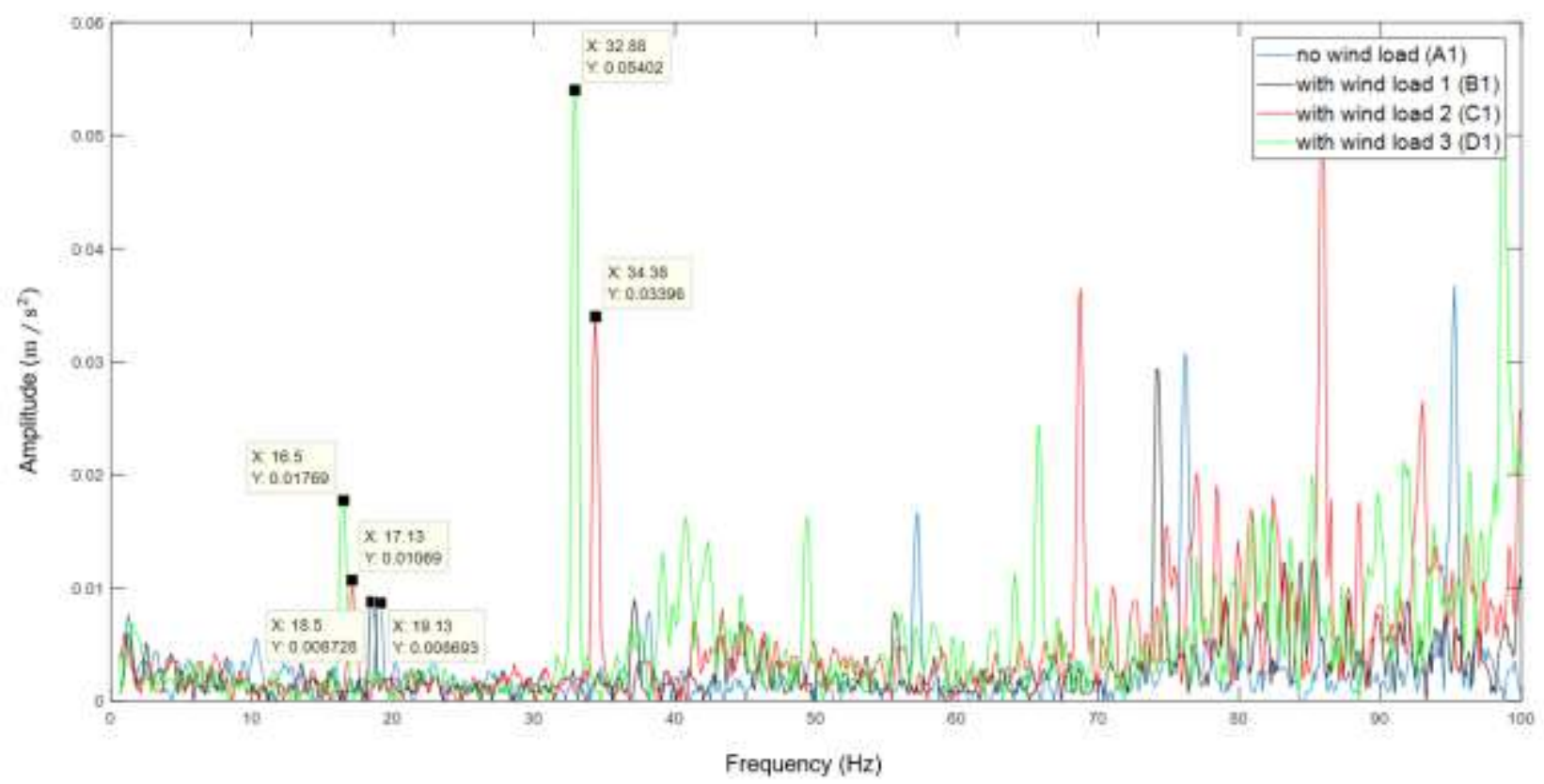

Source: Authors.

For the second experimental arrangement, the prototype was subjected to a 5-degree tilt (Figure 18), and a different behavior was observed in the spectral analysis. On the other hand, under tilted rotor operating conditions, a significant reduction in the fundamental amplitude under load was observed in conditions B2, C2, and D2. Also, increased wind load speed led to an amplitude increase caused by the blade's vibration.

For this experimental configuration, condition B1 presents an amplitude increase caused by the system inclination when simulating forward flight and, consequently, having a non-uniform load distribution in the structure.

Figure 19 - FFT - Rotor with a 5-degree inclination.

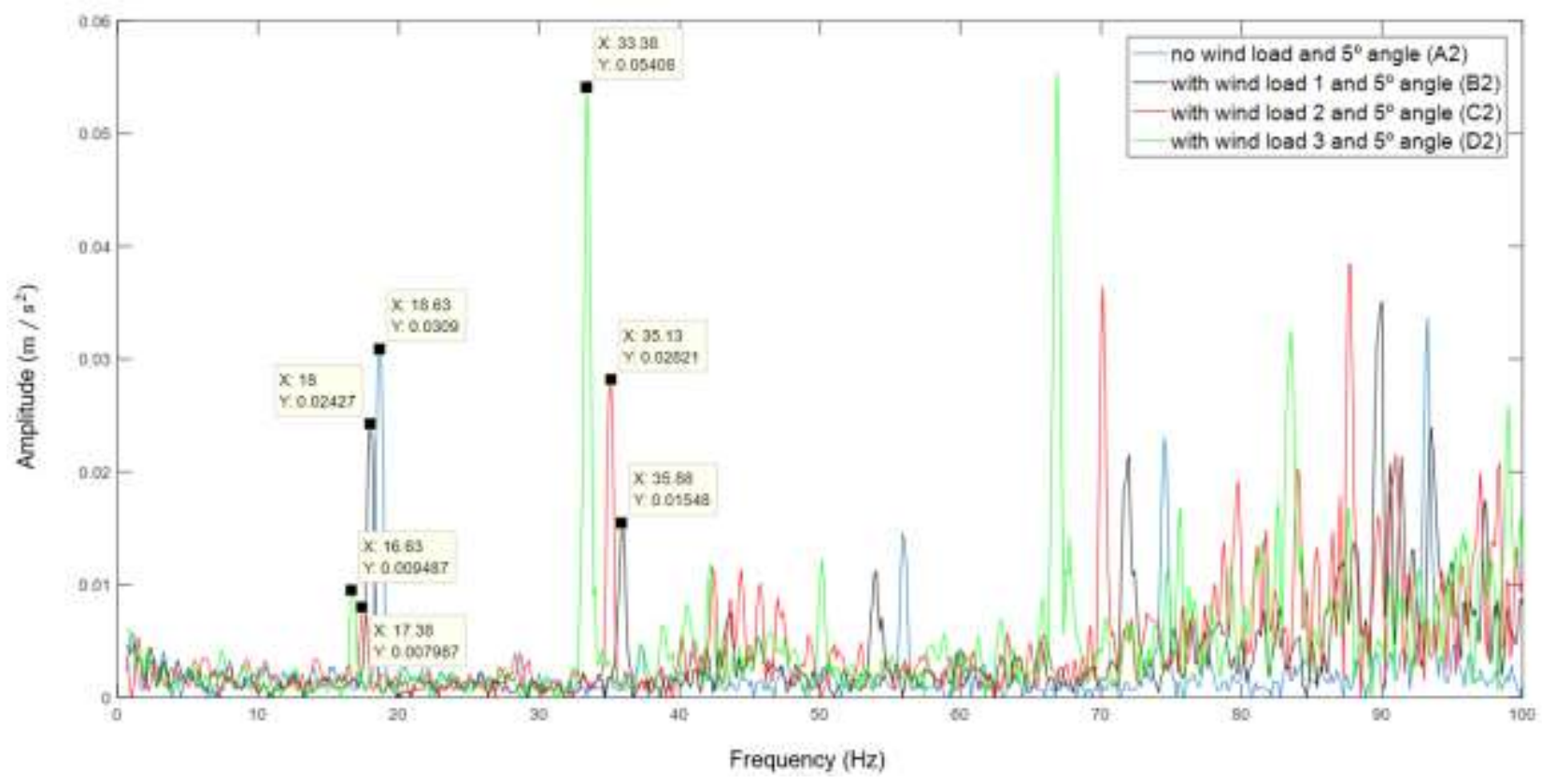

Source: Authors. 
In this paper, the ANN architecture uses a backpropagation algorithm to identify eight different working conditions. For the optimal ANN development, it was generated 40 different networks by varying the parameters to achieve the one that presents the best efficiency, as seen in Table 2.

In this process, the best network configuration was the one with a learning rate of 0.4 and 15 neurons in the hidden layer. This MLP reached 100\% efficiency, as shown by the confusion matrix presented in Figure 20.

By applying the MLP developed in this research, it was possible to detect undesirable vibrations under different flight conditions (forward and hover flight). Moreover, this MLP enables us to identify the wind load applied to the rotor in different situations, as shown in Figures 18 and 19.

Table 2 - Network parameters.

\begin{tabular}{|c|c|c|c|c|c|c|c|c|c|}
\hline \multicolumn{3}{|c|}{ Samples (\%) } & \multirow{2}{*}{$\begin{array}{c}\text { Noeurons } \\
\text { in hidden } \\
\text { layer }\end{array}$} & \multirow{2}{*}{ Learning rate } & \multirow{2}{*}{$\begin{array}{l}\text { Moment } \\
\text { constant }\end{array}$} & \multicolumn{4}{|c|}{ Precision (\%) } \\
\hline Training & Validation & Test & & & & Training & Validation & Test & All \\
\hline 70 & 15 & 15 & 5 & 0.1 & 0.1 & 84.8 & 79.2 & 70.8 & 81.9 \\
\hline 70 & 15 & 15 & 10 & 0.1 & 0.1 & 98.2 & 91.7 & 65.8 & 96.9 \\
\hline 70 & 15 & 15 & 15 & 0.1 & 0.1 & 83.9 & 91.7 & 75.0 & 83.8 \\
\hline 70 & 15 & 15 & 20 & 0.1 & 0.1 & 83.9 & 91.7 & 83.3 & 85.0 \\
\hline 70 & 15 & 15 & 25 & 0.1 & 0.1 & 71.4 & 58.3 & 83.3 & 71.3 \\
\hline 70 & 15 & 15 & 30 & 0.1 & 0.1 & 70.5 & 83.3 & 83.3 & 74.4 \\
\hline 70 & 15 & 15 & 35 & 0.1 & 0.1 & 86.6 & 91.7 & 83.3 & 86.9 \\
\hline 70 & 15 & 15 & 40 & 0.1 & 0.1 & 35.7 & 33.3 & 25.0 & 33.8 \\
\hline 70 & 15 & 15 & 45 & 0.1 & 0.1 & 40.2 & 16.7 & 41.7 & 36.9 \\
\hline 70 & 15 & 15 & 50 & 0.1 & 0.1 & 96.4 & 100 & 100 & 97.5 \\
\hline 70 & 15 & 15 & 5 & 0.4 & 0.1 & 82.1 & 79.2 & 70.8 & 80.0 \\
\hline 70 & 15 & 15 & 10 & 0.4 & 0.1 & 64.3 & 41.7 & 45.8 & 58.1 \\
\hline 70 & 15 & 15 & 15 & 0.4 & 0.1 & 100 & 100 & 100 & 100 \\
\hline 70 & 15 & 15 & 20 & 0.4 & 0.1 & 88.4 & 79.2 & 66.7 & 83.8 \\
\hline 70 & 15 & 15 & 25 & 0.4 & 0.1 & 98.2 & 91.7 & 87.5 & 95.6 \\
\hline 70 & 15 & 15 & 30 & 0.4 & 0.1 & 85.7 & 83.3 & 66.7 & 82.5 \\
\hline 70 & 15 & 15 & 35 & 0.4 & 0.1 & 87.5 & 75.0 & 79.2 & 84.4 \\
\hline 70 & 15 & 15 & 40 & 0.4 & 0.1 & 72.3 & 79.2 & 58.3 & 71.3 \\
\hline 70 & 15 & 15 & 45 & 0.4 & 0.1 & 49.4 & 41.7 & 58.3 & 49.4 \\
\hline 70 & 15 & 15 & 50 & 0.4 & 0.1 & 64.3 & 54.2 & 58.3 & 61.9 \\
\hline 70 & 15 & 15 & 5 & 0.7 & 0.1 & 89.3 & 91.7 & 70.8 & 86.9 \\
\hline 70 & 15 & 15 & 10 & 0.7 & 0.1 & 67.9 & 83.3 & 83.3 & 72.5 \\
\hline 70 & 15 & 15 & 15 & 0.7 & 0.1 & 100 & 100 & 91.7 & 98.8 \\
\hline 70 & 15 & 15 & 20 & 0.7 & 0.1 & 77.7 & 62.5 & 75.0 & 75.0 \\
\hline 70 & 15 & 15 & 25 & 0.7 & 0.1 & 76.8 & 70.8 & 70.8 & 75.0 \\
\hline 70 & 15 & 15 & 30 & 0.7 & 0.1 & 70.5 & 70.8 & 75.0 & 71.3 \\
\hline 70 & 15 & 15 & 35 & 0.7 & 0.1 & 99.1 & 95.8 & 83.3 & 96.3 \\
\hline 70 & 15 & 15 & 40 & 0.7 & 0.1 & 83.0 & 87.5 & 83.3 & 83.8 \\
\hline
\end{tabular}


Research, Society and Development, v. 10, n. 12, e304101220546, 2021

(CC BY 4.0) | ISSN 2525-3409 | DOI: http://dx.doi.org/10.33448/rsd-v10i12.20546

\begin{tabular}{cccccccccc}
\hline 70 & 15 & 15 & 45 & 0.7 & 0.1 & 75.9 & 75.0 & 66.7 & 74.4 \\
\hline 70 & 15 & 15 & 50 & 0.7 & 0.1 & 61.6 & 58.3 & 54.2 & 60.0 \\
\hline 70 & 15 & 15 & 5 & 1 & 0.1 & 15.2 & 12.5 & 4.2 & 13.1 \\
\hline 70 & 15 & 15 & 10 & 1 & 0.1 & 100 & 100 & 95.8 & 99.4 \\
\hline 70 & 15 & 15 & 15 & 1 & 0.1 & 87.5 & 83.3 & 91.7 & 87.5 \\
\hline 70 & 15 & 15 & 20 & 1 & 0.1 & 88.4 & 75.0 & 70.8 & 83.8 \\
\hline 70 & 15 & 15 & 25 & 1 & 0.1 & 83.9 & 83.3 & 79.2 & 83.1 \\
\hline 70 & 15 & 15 & 30 & 1 & 0.1 & 69.6 & 70.8 & 66.7 & 69.4 \\
\hline 70 & 15 & 15 & 35 & 1 & 0.1 & 76.8 & 66.7 & 75.0 & 75.0 \\
\hline 70 & 15 & 15 & 40 & 1 & 0.1 & 22.3 & 41.7 & 20.8 & 25.0 \\
\hline 70 & 15 & 15 & 45 & 1 & 0.1 & 33.9 & 33.3 & 29.2 & 33.1 \\
\hline 70 & 15 & 15 & 50 & 1 & 0.1 & 84.8 & 91.7 & 87.5 & 86.3 \\
\hline
\end{tabular}

Source: Authors.

Figure 20 - Confusion matrix.
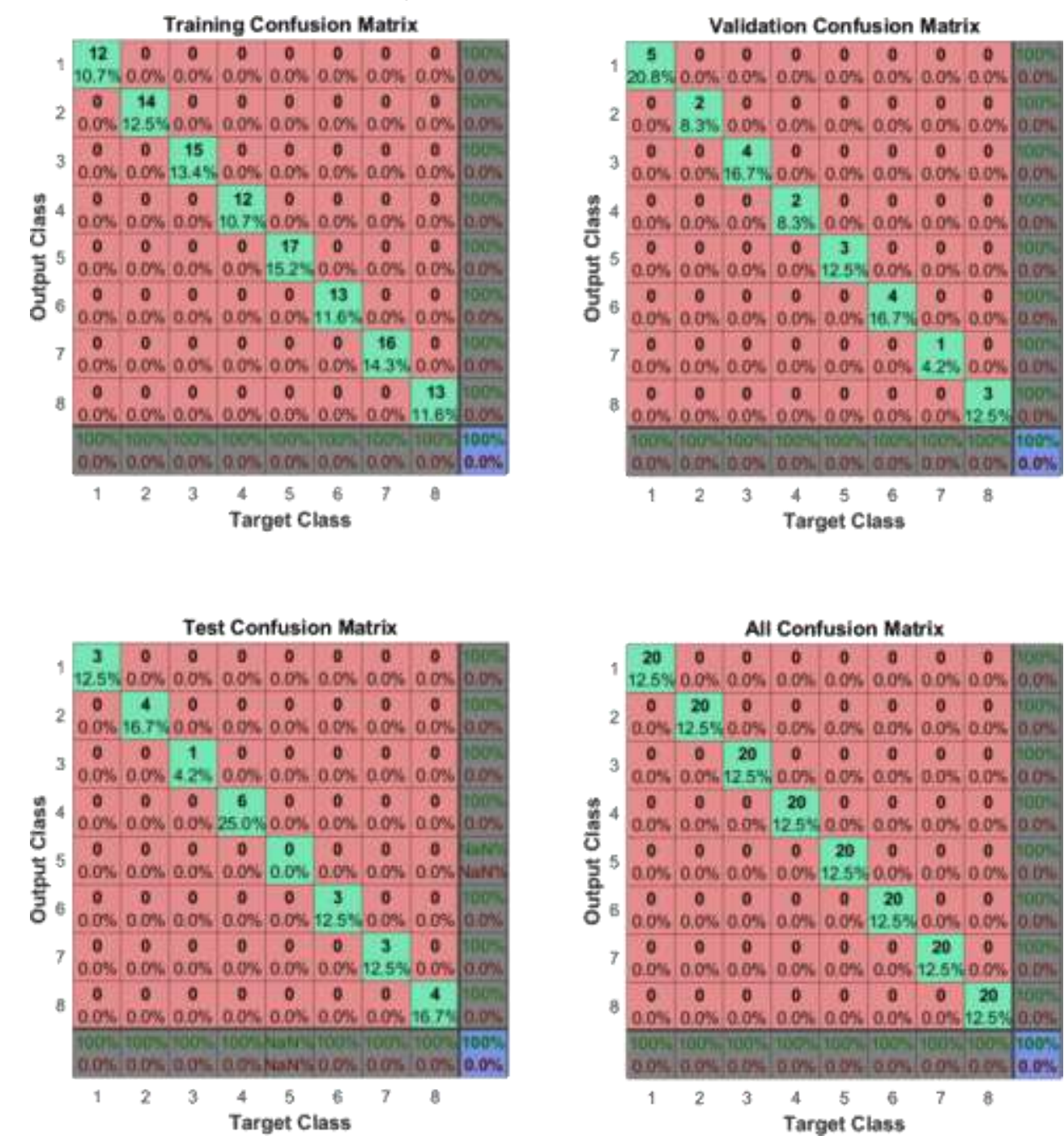

Source: Authors. 


\section{Conclusion}

The experimental results achieved in this paper are similar to the results obtained by other authors using a scaled prototype. Also, when compared to real helicopters, the prototype is efficient in describing actual working conditions based on their dynamic behavior.

For the helicopter prototype, vibration signals were analyzed under unbalanced conditions caused by different wind loads $(2,5$ and $10 \mathrm{~m} / \mathrm{s})$ and blades' inclination $\left(0\right.$ and $\left.5^{\circ}\right)$.

The vibration analysis indicated that different flight conditions of a helicopter may be identified from the amplitude behavior in its fundamental frequency and passage frequency of the blades.

In the first operating condition analyzed, in which the blades operated without inclination, the amplitudes of the fundamental frequency increased as the wind speed increased. The same amplitude behavior was observed for the first harmonic frequency.

For the tilted rotor, the amplitudes of the fundamental frequency increase as the wind loads increase. Regarding the first harmonic, similarly to the first operating condition, an increased amplitude was also observed with increasing wind load.

In both cases, the value of the fundamental frequency decreased because of the wind load. This frequency decrease may occur because of the low torque motor used to move the blades.

Additionally, we developed an ANN to recognize the operating conditions imposed on the prototype. This smart system reached an efficiency of $100 \%$ for the prototype working condition recognition and presented the following parameters: 15 neurons in the hidden layer, the learning rate of 0.4 , and a moment constant of 1.

The data indicate that the ANN allows a quick decision regarding vibration attenuation under undesirable flight conditions. Thus, the ANN may contribute to a safer use of the helicopter and increase its useful life.

\section{Acknowledgments}

This work was sponsored by the Paraiba Federal University, the Integrity and Inspection Research Laboratory (LABII/UFPB), the Vibration and Instrumentation Laboratory (UFCG), and the Coordination of Superior Level Staff Improvement (CAPES). The authors gratefully acknowledge these supports.

\section{References}

Bramwell, A. R. S., Done, G., \& Balmford, D. (2001). Bramwell's helicopter dynamics (Butterworth-Heinemann (ed.); Second). Butterworth-Heinemann.

Cavicchi, T. J. (1999). Digital Signal Processing. In John Wiley \& Sons. John Wiley \& Sons. https://doi.org/978-0471124726

CENIPA. (2017). Helicópteros sumário estatístico 2008-2017. https://www2.fab.mil.br/cenipa/

Ceruti, A., Liverani, A., \& Recanatesi, L. (2011). Improving Helicopter Flight Simulation with Rotor Vibrations. Proceedings of the IMProVe 2011 International Conference on Innovative Methods in Product Design, 636-645.

RTCA DO-160C, Pub. L. No. RTCA DO-160C, 33 (2014). http://do160.org/wp-content/uploads/RTCA-DO-357-Abstract-DO-160G-Guideline.pdf

Damy, L. F. (2006). Análise do Espectro de Frequência de Vibração da Aeronave Esquilo AS-355 F2. Istituto Tecnológico de Aeronáutica, São José dos Campos - SP

De Gregorio, F. (2012). Flow field characterization and interactional aerodynamics analysis of a complete helicopter. Aerospace Science and Technology. https://doi.org/10.1016/j.ast.2011.11.002

Doebelim, E. O. (1995). Engineering experimentation: planning, execution, reporting. Mcgraw-Hill Companies.

Dong, Y. (2018). An application of Deep Neural Networks to the in-flight parameter identification for detection and characterization of aircraft icing. Aerospace Science and Technology, 77, 34-49. https://doi.org/10.1016/j.ast.2018.02.026 
Research, Society and Development, v. 10, n. 12, e304101220546, 2021 (CC BY 4.0) | ISSN 2525-3409 | DOI: http://dx.doi.org/10.33448/rsd-v10i12.20546

EASA. (2021). Reduction in accidents caused by failures of critical rotor and rotor drive components through improved vibration health monitoring systems, RMT. 0711 (Issue 1). https://www.easa.europa.eu/sites/default/files/dfu/ToR RMT.0711 Issue 1.pdf

FAA. (2012a). FAA-H-8083-21A: Helicopter Flying Handbook. In U. S. D. of Transportation (Ed.), FAA-H-8083-21A. FAA.

FAA. (2012b). Helicopter Flying Handbook (Federal Aviation Administration (ed.)). Federal Aviation Administration. www.faa.gov

Ford, T. (1999). Vibration reduction and monitoring. Aircraft Engineering and Aerospace Technology, 71(1), 21-24. https://doi.org/10.1108/00022669910252105

Glowacz, A. (2018). Acoustic-based fault diagnosis of commutator motor. Electronics (Switzerland), 7(11). https://doi.org/10.3390/electronics7110299

Glowacz, A., Glowacz, W., Glowacz, Z., \& Kozik, J. (2018). Early fault diagnosis of bearing and stator faults of the single-phase induction motor using acoustic signals. Measurement: Journal of the International Measurement Confederation, 113(May 2017), 1-9. https://doi.org/10.1016/j.measurement.2017.08.036

Johnson, W. (1994). Helicopter Theory (3rd ed.). Dover Publications.

Nguyen, D. H., Liu, Y., \& Mori, K. (2018). Experimental Study for Aerodynamic Performance of Quadrotor Helicopter. Transactions of the Japan Society for Aeronautical and Space Sciences, 61(1), 29-39. https://doi.org/10.2322/tjsass.61.29

Pereira, A., Shitsuka, D., Parreira, F., \& Shitsuka, R. (2018). Metodologia da Pesquisa Científica. In Metodologia da Pesquisa Científica. UFSM. https://repositorio.ufsm.br/bitstream/handle/1/15824/Lic_Computacao_Metodologia-Pesquisa-Cientifica.pdf?sequence=1.

Sadegh, H., Mehdi, A. N., \& Mehdi, A. (2016). Classification of acoustic emission signals generated from journal bearing at different lubrication conditions based on wavelet analysis in combination with artificial neural network and genetic algorithm. Tribology International, 95, 426-434. https://doi.org/10.1016/j.triboint.2015.11.045

Sanz, J., Perera, R., \& Huerta, C. (2012). Gear dynamics monitoring using discrete wavelet transformation and multi-layer perceptron neural networks. Applied Soft Computing Journal, 12(9), 2867-2878. https://doi.org/10.1016/j.asoc.2012.04.003

Saravanan, N., \& Ramachandran, K. I. (2010). Incipient gear box fault diagnosis using discrete wavelet transform (DWT) for feature extraction and classification using artificial neural network (ANN). Expert Systems with Applications, 37(6), 4168-4181. https://doi.org/10.1016/j.eswa.2009.11.006

Silva, I. N., Spatti, D. H., \& Flauzino, R. A. (2010). Redes Neurais Artificiais Para Engenharia e Ciências Aplicadas. In ArtLiber (Ed.), São Paulo: Artliber $\left(2^{\circ}\right)$. Artliber

Straub, F. K., Anand, V. R., Lau, B. H., \& Birchette, T. S. (2018). Wind tunnel test of the SMART active flap rotor. Journal of the American Helicopter Society, 63(1), 1-16. https://doi.org/10.4050/JAHS.63.012002

Stupar, S., Simonović, A., \& Jovanović, M. (2012). Measurement and Analysis of Vibrations on the Helicopter Structure in Order to Detect Defects of Operating Elements. Scientific Technical Review, 62(1), 58-63.

Vance, J., Zeidan, F., \& Murphy, B. (2010). Machinery Vibration and Rotordynamics. John Wiley \& Sons, Inc. https://doi.org/10.1002/9780470903704.fmatter

Waqar, T., \& Demetgul, M. (2016). Thermal analysis MLP neural network based fault diagnosis on worm gears. Measurement: Journal of the International Measurement Confederation, 86, 56-66. https://doi.org/10.1016/j.measurement.2016.02.024

Wu, J. Da, \& Chan, J. J. (2009). Faulted gear identification of a rotating machinery based on wavelet transform and artificial neural network. Expert Systems with Applications, 36(5), 8862-8875. https://doi.org/10.1016/j.eswa.2008.11.020

Zagaglia, D., Zanotti, A., \& Gibertini, G. (2018). Analysis of the loads acting on the rotor of a helicopter model close to an obstacle in moderate windy conditions. Aerospace Science and Technology, 78, 580-592. https://doi.org/10.1016/j.ast.2018.05.019 